\title{
Millennials Attitude and Knowledge to Use Hand Sanitisers During the Covid-19 Pandemic
}

\author{
Setiyo Budi Santoso ${ }^{1}$, Amalia Ratna Puspitadewi ${ }^{2}$, Wachiddin M Huda ${ }^{3}$, Septi Wardani \\ $\left\{\right.$ sb@unimma.ac.id $\left.{ }^{1}\right\}$ \\ Department of Community and Clinical Pharmacy, Faculty of Health Science, Universitas \\ Muhammadiyah Magelang ${ }^{1,2}$ \\ Department of Informatic Engineering, Faculty of Engineering, Universitas Muhammadiyah \\ Magelang ${ }^{3}$ \\ Department of Nursing, Faculty of Health Science, Universitas Muhammadiyah Magelang ${ }^{4}$
}

\begin{abstract}
In humans, the coronavirus can cause respiratory tract infections which are generally mild, like flu from the symptoms. The general public thinks it is only a common cold. However, for health workers, this virus is classified as dangerous and deadly. The government provides preventive steps to stop the spread of COVID-19, namely washing hands. This hand sanitiser product contains antiseptic properties used to kill bacteria on the hands, consisting of alcohol and triclosan. Questionnaire-based research was conducted to focus on empowering millennial attitudes and knowledge about the use of hand sanitisers during the COVID-19 pandemic. A total of 250 participants participated in the discussion via the Whatsapp group. However, the respondents in this study were only 96 respondents for the pre-test and 32 respondents for the post-test. The results showed that there is still a need for education to the public about hand sanitisers.
\end{abstract}

Keywords: Infection, Pre-test, Post-test, Whatsapp

\section{Introduction}

Coronavirus is an RNA virus that has a particle size of $120-160 \mathrm{~nm}$. This virus usually infects the animals; bats and camels are mainly infected [1]. In humans, the coronavirus can cause respiratory tract infections that are generally mild, such as cold symptoms. Ordinary people think it is only limited to ordinary influenza, but this virus is quite dangerous and deadly for health workers. In 2020, this virus transmission's growth was quite significant because it has spread worldwide, and many countries feel the impact, including Indonesia [2]. The covid-19 firstly reported in Indonesia on March 2, 2020, with 2 cases confirmed. On March 31, 2020, the data showed 1,528 people infected, and 136 died. The mortality rate for covid-19 in Indonesia is $8.9 \%$. It is the highest rate in Southeast Asia [1].

The covid-19 that increase rapidly causes society to get panic. Because the government gives the preventive steps to stop the spreading the covid-19, that washes the hand [3]. Washing your hands using soap that is appropriately practised and correctly is the easiest and most efficient method to avoid contracting diseases such as diarrhoea, cholera, acute respiratory infection, worms, flu, hepatitis A, and even bird flu. Washing hands with soap and water can more efficiently remove dirt and dust from the skin's surface and significantly reduce the number of disease-causing microorganisms such as viruses, germs, and other parasites on both hands [4]. The weakness is that not all places provide handwashing facilities, so the alternatives are 
using hand sanitiser. This hand sanitiser product contains antiseptic properties used to kill bacteria on the hands, consisting of alcohol and triclosan. The types of hand sanitiser products are also increasingly diverse, both in terms of composition, substance, and new products widely used in the general public have been marketed [4].

Some people do not understand how to use the hand sanitiser, some of them use the hand sanitiser incorrectly or too much. So, because of the reasons, this research conducted through the Whatsapp group. The purpose of this research is to make people understand how to use the hand sanitiser correctly.

\section{Method}

The research design is a descriptive analysis to assess millennials' attitudes and knowledge in Central Java about the use of hand sanitisers during the Covid-19 pandemic. A total of 250 participants took part in the discussion via the WhatsApp group. However, the respondents in this study were 96 respondents for the pre-test and 32 respondents for the post-test. The questionnaire was prepared to collect data consisting of six parts, demographic data, frequency of use of hand sanitisers, knowledge, attitudes, and respondents' opinions.

The discussion forum organisers make rules to run smoothly, such as disabling chat in the group when the speaker delivers the material. Questions raised by participants to presenters must be sent to the moderator. Group chat will be activated when the discussion session is held. The discussion was held on May 2, 2020, and participants know about this event discussion through pamphlets distributed by the committee a week before the event started from social media. The activity was carried out from May 1 to 3, 2020. On May 1, 2020, it was used to fill out the questionnaire one day before the discussion started (pre-test), and the 3rd was used to fill out the questionnaire one day after the discussion was finished (post-test).

\section{Results and Discussion}

\subsection{Result}

Our results in Figure 1 show that millennial attitudes and knowledge after discussion increased from a frequency of $86.50 \%$ to $90 \%$. The majority of them $(60 \%)$ agree that hand sanitiser is for cleaning their body parts. Even so, only half of them is committed to using hand sanitisers while travelling. This commitment was also confirmed by the readiness of $43 \%$ of them always to carry hand sanitiser when travelling. The majority do not set a standard for the maximum volume smeared on their hands regarding the volume of use. 


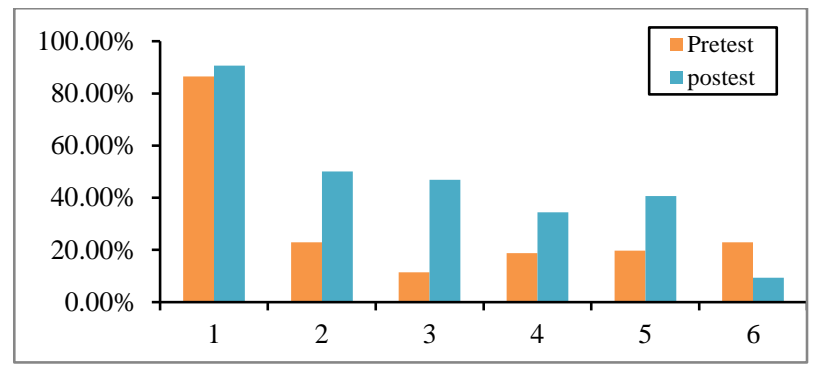

Note:

1. Purpose of use to clean body parts

2. Use when travelling (Often)

3. Use at home (Often)

4. Validate the frequency of use (Every day)

5. Maximum Frequency (6-8 times)

6. Usage volume (as you like)

Fig. 1. Millennial attitude about hand sanitisers

After we invited millennials to discuss show in Figure 2, most of them (69\%) realised that making hand sanitisers is not as simple as diluting some chemical compounds to a certain level. Even so, they (53\%) understand that hand-sanitiser preparations can be produced independently. This understanding is also accompanied by awareness $(81 \%)$ that independent production products that the food and drug regulatory agency do not register cannot be distributed and commercialised.

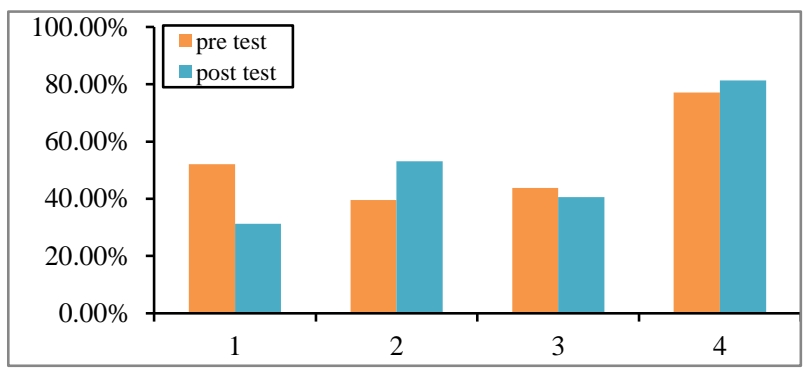

Note:

1. How to Make Handsanitisers
(disagree)

2. Independent Production (agree)

3. Composition (disagree)

4. Commercialization / distribution (agree)

Fig. 2. Millennial perception about hand sanitisers

In our exploration of millennial perceptions, after they finished the discussion, most of them still believed that washing hands with soap is better than cleaning them with a hand sanitizer show in Figure 3. Although the number after post-test has decreased (13.5\%). This perception may be related to most of them $(72.5 \%)$ believe that handsanitisers do not irritate. Even so, only a minority of them believe that the handsanitiser can kill germs $100 \%$. We are also proud to find that most of them $(72 \%)$ believe that hand sanitisers do not cause resistance to the Covid-19.

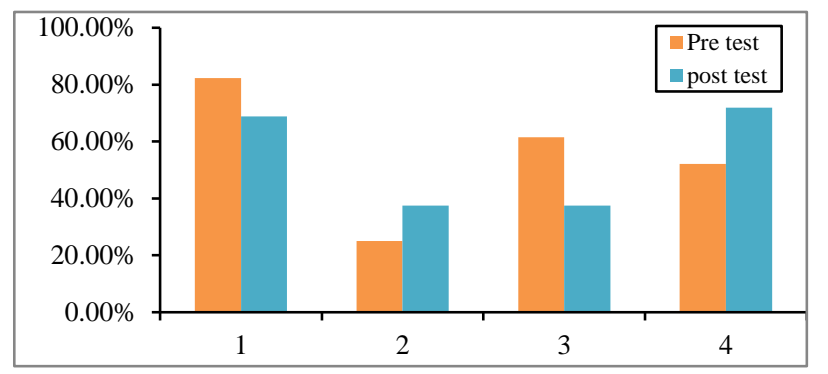

Note:

1. Soap is better than a Handsanitisers (agree)

2. Handsanitisers kills $100 \%$ of Covid (agree)

3. Repeated use of Handsanitisers causes irritation (disagree)

4. Repeated use triggers covid resistance (disagree)

Fig. 3. Millennial perception about hand sanitisers 


\subsection{Discussion}

When the Covid19 pandemic hits. We realise that not everyone is ready with various actions to deal with it. The simple thing for self-protection is the awareness to apply the discipline of cleaning hands. One of the alternatives is to use a hand sanitiser. We feel the need to investigate and do a little bit to intervene in them so that their attitudes, understanding, and perceptions about hand sanitisers align with the correct directions. This effort is a form of our consistency in describing problems of attitude, knowledge and perceptions as we have done before [5], [6] also with the willingness of pharmacists to develop roles outside the dispensing area [7], [8].

Indeed, it a piece of good news that millennials have a cooperative attitude about hand sanitisers. As with other publications, they believe that these fluids are safe for body parts [9], [10]. More than that, they are also ready to use and carry it when traveling. This target should be what we all hope to break the chain of transmission of Covid19 [11].

We explained some facts about hand sanitisers during discussions with them. This explanation is vital so that their knowledge is not misleading. They need to understand that the hand sanitiser formula, as recommended by the World Health Organization, consists of three main ingredients; Ethanol (80\%), glycerol (1.45\%), and hydrogen peroxide $(0.125 \%)$. Supporting media needed in the production process can use the following alternatives: distilled water (aqua dest), sterile water, or boiled water cooled [12]- [14]. With the regulation of the liquid distribution permit, we did not escape from explaining, so there would be no regulatory violations [15].

In perception, we try to correct them with a report that states that the frequency of handwashing can take place 20-30 times per shift [11]. It is also essential to believe that a handsanitiser can kill germs less than 30 seconds [3]. Regarding the regulation of health products, we emphasise that hand sanitiser is a Class II household health product. It means that these products can cause effects such as irritants, corrosives for those who use them, although they do not cause serious consequences such as carcinogenic [15]- [17]. Concerning the potential for resistance, they need to have a frame of mind that alcohol-based products work to kill viruses by damaging microorganisms' physiology. This mechanism differs from antibiotics which work enzymatically or involve bacterial receptors [18]. The use of hand sanitiser also does not potentially cause potential drug interactions like oral drugs [19].

Our research results are certainly not strong enough to describe all millennials with various types and characteristics. Even so, this is a portrait that is happening around us. An important point that we emphasize, although we discussed using the WhatsApp platform, improvements in attitudes, knowledge and perceptions can occur. We recommend the three components mentioned in the future related to problems of quality of life, and toughness in using the product in the long term, as part of the research we have applied before [5], [20], [21].

\section{Conclusion}

The use of hand sanitisers has become a necessity for millennials to face the pandemic. The discussion through Whatsapp can improve attitudes, knowledge and perceptions of hands-on agents. The method we have used can be applied for educational activities on the practical use of similar pharmaceutical products. 


\section{Acknowledgement}

We would like to thank the millenial of who have been willing to fill out our research questionnaire

\section{References}

[1] A. Susilo et al., 'Coronavirus Disease 2019: Tinjauan Literatur Terkini', J. Penyakit Dalam Indones., vol. 7, no. 1, p. 45, 2020, doi: 10.7454/jpdi.v7i1.415.

[2] N. R. Yunus and A. Rezki, 'Kebijakan Pemberlakuan Lock Down Sebagai Antisipasi Penyebaran Corona Virus Covid-19', SALAM J. Sos. Dan Budaya Syar-I, vol. 7, no. 3, pp. 227-238, 2020, doi: 10.15408/sjsbs.v7i3.15083.

[3] R. Nakoe, N. A. S Lalu, and Y. A. Mohamad, 'Perbedaan Efektivitas Hand-Sanitizer Dengan Cuci Tangan Menggunakan Sabun Sebagai Bentuk Pencegahan Covid-19', Jambura J. Health Sci. Res., vol. 2, no. 2, pp. 65-70, 2020, doi: 10.35971/jjhsr.v2i2.6563.

[4] F. A. Desiyanto and S. N. Djannah, 'Efektivitas Mencuci Tangan Menggunakan Cairan Pembersih Tangan Antiseptik (Hand Sanitizer) Terhadap Jumlah Angka Kuman', J. Kesehat. Masy. J. Public Health, vol. 7, no. 2, pp. 75-82, 2013, doi: 10.12928/kesmas.v7i2.1041.

[5] S. B. Santoso, H. Lutfiyati, R. I. Prasidha, S. Ratnafuri, and K. A. Azzahra, 'What do patients with HIV-infection perceive and know regarding to antiretrovirals? An exploration among participants undergoing controlled-therapy', Technol. Rep. Kansai Univ., vol. 62, no. 04, p. 7, 2020.

[6] P. Pribadi, R. C. A. Pangestuti, H. Lutfiyati, E. Latifah, and S. B. Santoso, 'The Knowledge and Attitude of Universitas Muhammadiyah Magelang Pharmacy Students on National Health Programs-a Descriptive Study', presented at the 1st Borobudur International Symposium on Humanities, Economics and Social Sciences (BIS-HESS 2019), Magelang, Indonesia, 2020, doi: 10.2991/assehr.k.200529.154.

[7] H. Lutfiyati, P. Pribadi, and S. B. Santoso, 'Kesiapan Apoteker dalam Memberikan Layanan Medication Therapy Management', CERATA J. Ilmu Farm., vol. 10, no. 1, p. 5, 2019.

[8] H. Lutfiyati, B. Mintarsih, S. B. Santoso, and D. K. Dewi, 'Evaluasi Sumber Daya Apoteker Berdasarkan Standar Pelayanan Kefarmasian Terkait Sumber Daya Manusia di Apotek Kabupaten Temanggung', presented at the Prosiding Pertemuan Ilmiah Daerah IAI PD Jawa Tengah 2020, Surakarta, Indonesia, 2020.

[9] D. W. Dewi, S. Khotimah, and D. F. Liana, 'Pemanfaatan Infusa Lidah Buaya ( Aloe vera L ) sebagai Antiseptik Pembersih Tangan terhadap Jumlah Koloni Kuman', J. Cerebellum, vol. 2, no. 3, pp. 577-589, 2016.

[10] P. Liu, Y. Yuen, H.-M. Hsiao, L.-A. Jaykus, and C. Moe, 'Effectiveness of Liquid Soap and Hand Sanitizer against Norwalk Virus on Contaminated Hands', Appl. Environ. Microbiol., vol. 76, no. 2, pp. 394-399, Jan. 2010, doi: 10.1128/AEM.01729-09.

[11] F. D. A. Pinasti, 'Analisis Dampak Pandemi Corona Virus Terhadap Tingkat Kesadaran Masyarakat dalam Penerapan Protokol Kesehatan', Wellness Healthy Mag., vol. 2, no. 2, pp. 237-249, 2020 doi: $10.30604 /$ well.022.82000107.

[12] H. Kaur and R. Keshri, 'Production of Ethanol from Sugarcane Molasses', Int. J. Res. Appl. Sci. Biotechnol., vol. 7, no. 5, pp. 93-97, 2020, doi: 10.31033/ijrasb.7.5.13.

[13] G. S. Thompson, Understanding Anatomy \& Physiology: A Visual, Auditory, Interactive Approach, 2nd edition. Philadelphia: F.A. Davis Company, 2015.

[14] World Health Organization and United Nations Children's Fund (UNICEF, 'Water, sanitation, hygiene, and waste management for the COVID-19 virus.pdf'. WHO \& UNICEF, 2020.

[15] Peraturan Menteri Kesehatan Nomor 1190/Menkes/Per/VIII/2010. . 
[16] A. Asngad and A. B. R, 'Kualitas Gel Pembersih Tangan ( Handsanitizer ) dari Ekstrak Batang Pisang dengan Penambahan Alkohol, Triklosan dan Gliserin yang Berbeda Dosisnya', vol. 4, no. 2, pp. 61-70, 2018, doi: 10.23917/bioeksperimen.v4i1.2795.

[17] A. Chang et al., 'Cleaning and Disinfectant Chemical Exposures and Temporal Associations with COVID-19 - National Poison Data System, United States, January 1, 2020-March 31, 2020', MMWR Morb. Mortal. Wkly. Rep., vol. 69, no. 16, pp. 496-498, Apr. 2020, doi: 10.15585/mmwr.mm6916e1.

[18] E. P. Rini and E. R. Nugraheni, 'Uji Daya Hambat Berbagai Merek Hand Sanitizer Gel Terhadap Pertumbuhan Bakteri Escherichia coli dan Staphylococcus aureus', JPSCR J. Pharm. Sci. Clin. Res., vol. 3, no. 1, p. 18, 2018, doi: 10.20961/jpscr.v3i1.15380.

[19] S. B. Santoso and M. Azalea, 'Potensi Interaksi Antibiotik dengan Obat Penyerta pada Peresepan Pasien ISPA Dan PPOK', CERATA J. Ilmu Farm., vol. 9, no. 1, p. 8, 2018.

[20] S. B. Santoso, D. A. Perwitasari, I. N. Faridah, and A. A. Kaptein, 'Hubungan Kualitas Hidup Dan Persepsi Pasien Tentang Penyakit Diabetes Mellitus Tipe 2 Dengan Komplikasi', Pharmaciana, vol. 7, no. 1, p. 33, 2017, doi: 10.12928/pharmaciana.v7i1.4699.

[21] D. A. Perwitasari, S. B. Santosa, I. N. Faridah, and A. A. Kaptein, 'Illness Perceptions and Quality of Life in Patients with Diabetes Mellitus Type 2', Indones. J. Clin. Pharm., vol. 6, no. 3, pp. 190 199, 2017, doi: 10.15416/ijcp.2017.6.3.190. 